\title{
THE ANNUAL MEETING IN PHILADELPHIA
}

The sixty-fifth annual meeting of the American Mathematical Society was held on Tuesday, Wednesday, and Thursday, January 20-22, at the University of Pennsylvania in Philadelphia, Pennsylvania, in conjunction with meetings of the Mathematical Association of America, The Association for Symbolic Logic, and The Delaware Valley Section of the Society for Industrial and Applied Mathematics. Sessions took place in the Physical Sciences Building, the Moore School Building, and the University Museum. The total registration was 996 including 741 members of the Society.

The thirty-second Josiah Willard Gibbs Lecture was delivered by Professor J. M. Burgers at 8:00 P.M. on Tuesday in the University Museum Auditorium. His subject was On the emergence of patterns of order. The President, Professor E. J. McShane, introduced the speaker.

By invitation of the Committee to Select Hour Speakers for Annual and Summer Meetings, there were two addresses. Professor G. D. Mostow of The Johns Hopkins University spoke on Compact transformation groups on Tuesday at 2:00 P.M. and Professor Felix Browder of Yale University spoke on The spectral theory of partial differential operators on Wednesday at 2:00 P.M. Both addresses were given in the University Museum Auditorium, with Professor Leo Zippin presiding at the first and Professor J. J. Stoker presiding at the second.

On Wednesday afternoon at 2:00 P.M. at a general session in the University Museum, President McShane presiding, the Bôcher Prize in Analysis was awarded to Professor Louis Nirenberg of New York University for his work in Partial Differential Equations. The prize was awarded by the Council of the Society upon the recommendation of a committee consisting of Professor Salomon Bochner, Chairman, and Professors D. V. Widder and J. L. Doob. The citation was made by Professor Lipman Bers.

The University of Pennsylvania held a reception for mathematicians and their guests on Wednesday from 4:00 to 6:00 P.M. in the Rotunda of the University Museum.

A banquet took place at the Benjamin Franklin Hotel on Thursday at 7:00 P.M. Professor J. S. Frame chose this occasion to present a resolution of thanks to the hosts of the meeting from the mathematical organizations meeting concurrently; it was adopted unanimously by acclamation.

There were twenty-four sessions for contributed papers, including 
two sessions for late papers, and a supplementary program of papers presented by title. The presiding officers were Professors K. L. Chung, H. S. M. Coxeter, C. L. Dolph, Robert Ellis, G. F. Feeman, Murray Gerstenhaber, Casper Goffman, Theodore Hailperin, MaryElizabeth Hamstrom, Melvin Henriksen, Dr. J. H. Hodges, Professors T. L. Koehler, Lee Lorch, Dr. H. D. Mills, Professors L. F. Markus, B. E. Rhoades, Hans Rademacher, Walter Rudin, C. W. Saalfrank, Samuel Schechter, I. J. Schoenberg, H. W. E. Schwerdtfeger, Seymour Sherman, and Domina E. Spencer.

Abstracts of papers presented in person and by title, appear in the Notices of the American Mathematical Society for December (Issue No. 35) and February (Issue No. 36).

The Council met on Wednesday afternoon and evening, January 21, 1959.

The Secretary announced the election of the following eighty-six persons to ordinary membership in the Society:

Mr. L. R. Abramson, Columbia University;

Mr. A. C. Ahlin, Massachusetts Institute of Technology;

Mr. B. C. Awasthi, University of West Virginia;

Professor Goro Azumaya, Northwestern University;

Mr. D. O. Banks, Carnegie Institute of Technology;

Mr. P. F. Baum, Ecole Normale Superioure, France;

Mr. Murray Berg, Standard Oil Company, San Francisco, California;

Mr. G. A. W. Boehm, Fortune Magazine, New York, New York;

Mr. S. R. Branell, American Hydrotherm Corporation, Long Island City, New York;

Mr. L. K. Brathwaite, Computer Control Company, Los Angeles, California;

Mr. R. R. Brown, International Business Machines Corporation, Los Angeles, California;

Professor J. P. Burling, Oneonta State Teachers College;

Mr. W. G. Chinn, School Department, San Francisco, California;

Reverend A. A. Clarke, S. J., Fordham University;

Professor D. A. Clock, Northern Michigan College;

Mr. Aaron Cohen, CONVAIR Astronautics, San Diego, California;

Mr. L. J. Cohen, Remington Rand UNIVAC, Philadelphia, Pennsylvania;

Mr. A. G. Constantine, University of Adelaide, Adelaide, South Australia;

Professor A. A. Costa, Universität Lissabon;

Miss Marion E. Crider, West Georgia College;

Professor G. L. Crumley, The Citadel;

Dr. Bruno Dejon, Brookhaven National Laboratory, New York, New York;

Mr. Peter Dorato, Polytechnic Institute of Brooklyn;

Mr. T. M. Downie, General Dynamics Corporation, Groton, Connecticut;

Mr. R. P. Emig, II, University of California, Los Angeles;

Mr. J. R. Enterline, New York University;

Miss Sarah R. Evangelista, Temple University;

Mr. Arwel Evans, University of Western Ontario;

Mr. A. M. Fink, Iowa State College;

Mr. M. V. Fiondella, Rhode Island College of Education; 
Mr. F. A. Florio, Naval Air Material Center, Philadelphia, Pennsylvania;

Mr. J. G. S. Flym, Columbia University;

Mr. A. M. Foley, Crucible Steel Company of America, Pittsburgh, Pennsylvania;

Dr. D. R. Fulkerson, RAND Corporation, Santa Monica, California;

Mr. Allen Gold, University of Chicago;

Brother J. F. Gray, S. M., St. Mary's University;

Mr. J. R. Greenaway, Sylvania Electric Products Incorporated, Camillus, New York;

Mr. F. J. Hardy, McClellan Air Force Base, California;

Dr. S. M. Harmon, University of California, Los Angeles, California;

Mr. D. J. Hickman, Mississippi Vocational College;

Mr. D. L. Hickman, Mississippi Vocational College;

Mr. R. E. Holzman, Sylvania Electric Company, Needham Heights, Massachusetts;

Mr. J. R. Howell, University of Dayton;

Professor H. L. Hunzeker, University of Nebraska;

Mr. R. E. Kalman, RIAS, Incorporated, Baltimore, Maryland;

Mr. S. W. Kaye, Flight Refueling, Incorporated, Baltimore, Maryland;

Mr. J. C. Keith, University of Detroit;

Mr. Paul Kenneth, Grumman Aircraft Engineering Corporation, Bethpage, New York;

Mr. J. V. Kenny, New Jersey State Highway Department, Rockaway, New Jersey;

Mr. J. D. Kettelle, Kettelle \& Wagner, Paoli, Pennsylvania;

Mr. T. W. Khiralla, Buckingham-Khiralla Associates, Belmont, Massachusetts;

Professor J. R. Knudsen, New York University;

Professor Eiji Kometani, Kyoto University;

Mr. R. S. Kuehne, Shell Oil Company, Wood River, Illinois;

Professor Norman Levine, University of Pittsburgh;

Dr. Azriel Levy, Massachusetts Institute of Technology;

Professor E. T. Lucas, Oklahoma Baptist University;

Professor C. W. Lytle, Drew University;

Mr. E. H. Majewski, Johnson Service Company, Milwaukee, Wisconsin;

Miss Madeline D. Messner, Abraham Clark High School, Roselle, New Jersey;

Dr. W. S. Mitchell, King's College;

Professor D. E. Myers, Millikin University;

Dr. C. A. Muses, The Falcon's Wing Press, Indian Hills, Colorado;

Dr. Hirosi Nagao, University of Michigan;

Dr. H. L. Oestreicher, Wright Patterson Air Force Base, Ohio;

Dr. Kotaro Oikawa, University of California, Los Angeles;

Professor C. P. Parel, University of the Phillippines;

Mr. H. J. Passerini, Naval Research Laboratory, Washington, D. C.

Mr. M. H. Qualls, Sarkes Tarzian, Incorporated, Bloomington, Indiana;

Mr. J. L. Ravesloot, International Business Machines Research Laboratory, Yorktown, New York;

Mr. D. S. Ray, University of Tennessee;

Mr. A. H. Schainblatt, CONVAIR Astronautics, San Diego, California;

Mr. F. J. Schnitzer, Wayne State University;

Mr. Andreas Schopf, National Bureau of Standards, Washington, D. C.;

Mr. R. M. Sorensen, University of Maryland;

Mrs. Bobbie E. J. Sparks, Naval Air Development Center, Johnsville, Pennsylvania;

Mr. A. T. Spaulding, North Carolina Mutual Life Insurance Company, Durham, North Carolina; 
Professor K. L. Stellmacher, University of Maryland;

Professor R. A. Stokes, University of Mississippi;

Mr. Melvin Tainiter, Fairchild Guided Missile Division, Wyandanch, New York;

Professor M. F. Tinsley, Florida State University;

Mr. Tibor Tompa, International Business Machines Corporation, Philadelphia, Pennsylvania;

Mrs. Grace G. Wahba, Operations Research, Incorporated, Silver Spring, Maryland;

Dr. A. I. Weinzweig, University of California, Berkeley;

Mr. R. E. Williams, Scope, Incorporated, Fairfax, Virginia;

Mr. R. D. Wittner, Sperry Gyroscope Company, Great Neck, New York

It was reported that the following one hundred and eighty-seven persons had been elected to membership on nomination of institutional members as indicated:

Alabama Polytechnic Institute: Mr. J. D. Gilbert.

University of Arizona: Mr. Paul Aizley.

University of British Columbia: Mr. J. C. Ahuja, Mr. O. P. Bagai, Mr. Q. K. Ghori, Dr. N. A. Khan, Mr. Elöd Macskásy, Mr. Hensyk Minc, Mr. Auyuab Mohammed, Mr. Michael Schulzer.

Brown University: Mr. Edmund Eisenberg, Mr. A. T. Lundell, Professor R. E. Meyer.

University of California, Los Angeles: Mr. George Epstein, Mr. R. S. Grote, Mr. J. F.

Mount, Mr. Melvin Rosenfeld, Mr. Yasutaka Sibuya, Mr. G. G. Weill, Mr.

W. L. Wilson, Jr.

Catholic University of America: Reverend A. P. Whitman, S.J., Mr. D. J. Gallo.

University of Chicago: Mr. E. R. Berkson, Mr. R. E. Macrae, Mr. W. F. Pohl, Dr. Helmut Röhrl.

Columbia University: Mr. Irving Adler, Mr. E. A. Feldman, Mr. L. T. Gardner, Jr., Mrs. Estelle F. Goldberg, Mr. Frederick Hoffman, Mr. G. A. Hutchinson, Mr. F. E. J. Linton, Mr. R. A. Mayer, Jr., Mr. J. B. Seldin, Miss Ellen Shapiro, Mr. R. Sridharan, Mr. Erling Stфrmer, Mr. J. E. Strum, Mr. J. A. Thorpe.

Cornell University: Mr. M. A. Arkowitz, Mr. J. H. Bennett, Miss Naomi Bograd, Mr.

G. E. Brown, Mr. R. R. Cuykendall, Mr. F. M. Djorup, Jr., Mr. B. W. Glickfeld, Mr. C. A. Haynie, Professor P. J. Hilton, Dr. R. C. N. Hourston, Mr. R. D. Joseph, Mr. A. G. Konheim, Mr. Samuel Kotz, Mr. J. L. Leonard, Mr. D. A. Lind, Mr. R. L. London, Miss Ellen J. Lorber, Miss Virginia W. Morriss, Mr. D. S. Newman, Mrs. Barbara L. Osofsky, Mr. G. J. Porter, Mr. H. C. Ruck, Mr. G. E. Sacks, Miss Virginia A. Walbran, Mrs. Carol E. Wolf.

De Paul University: Mr. R. F. Frankowski.

Duke University: Mr. R. J. Roth, Mr. H. R. Stevens.

Harpur College: Mr. R. L. Goodrich.

Illinois Institute of Technology: Mr. F. F. Connor.

University of Illinois: Mr. J. A. Berton, Mr. J. R. Boen, Mr. J. A. Ernest, Mr. R. H. Farrell, Mr. R. T. Harris, Mr. C. A. Long, Mr. D. H. Lorenz, Dr. Morio Obata, Mr. J. H. Oppenheim, Mr. Rajinder Singh, Mr. R. A. Stafford, Mr. Mudomo Sudigdomarto, Mr. Alan Troy, Mr. R. A. Welker.

Institute for Advanced Study: Mr. Shôrô Araki, Dr. K. D. Aubert, Dr. U. H. R. O. Christian, Dr. Branko Grünbaum, Dr. Woldram Jehne, Dr. Hisasi Morikawa, Professor Minoru Nakaoka, Dr. Ichiro Satake, Professor Roman Sikorski, Professor Edoardo Vesentini.

Lehigh University: Mr. I. D. Berg, Mr. K. C. Bouchelle, Mr. M. F. Hertzog. 
Massachusetts Institute of Technology: Mr. L. J. Wallen, Mr. R. L. Bishop, Mr. P. L. Duren, Mr. T. G. Evans, Mr. Michael Ginsburg, Mr. I. N. Katz, Mr. J. B. Muskat, Mr. Hugo Rossi, Mr. J. W. Schlesinger, Mr. R. G. Sinclair, Mr. J. R. Slagle.

University of Michigan: Mr. D. A. Foulser, Mr. Arnold Lebow, Mr. F. W. Leysieffer, Mr. G. P. Patil, Mr. J. H. Stroddard.

University of Missouri: Mr. E. Z. Andalafte, Mr. R. W. Freese, Mr. R. F. Keller.

University of Nebraska: Mr. Konrad Suprunowicz.

University of North Carolina: Mr. J. M. Gwynn, Jr., Mr. J. B. Linder, Mr. A. C. Mewborn, Mr. Prabir Roy, Mr. J. E. Shockley.

University of Oregon: Mrs. Barbara T. Chicks, Mr. P. M. Cuttle, Mr. L. C. Eggan, Mr. R.E. Haymond.

University of Pennsylvania: Mr. Michael Barr, Mrs. Regina B. Cohen, Mr. J. A. Dale, Mr. F. A. Dunn, Jr., Miss Betty R. Estes, Mr. R. C. Glaeser, Mr. D. L. Goldsmith, Miss Kathryn R. Hibbs, Dr. Mildred T. Kramer, Miss Marianne Silverstein, Miss Mary B. Williams.

Princeton University: Mr. D. M. Brown, Mr. Armand Brumer, Mr. D. S. Burdick, Mr. D. J. C. Bures, Mr. E. C. Dade, Dr. H. E. Debrunner, Mr. J. D. Dollard, Mr. D. A. Freedman, Mr. P. J. Freyd, Mr. Martin Fuchs, Mr. J. L. Gastwirth, Mr. H. R. Gluck, Mr. Newcomb Greenleaf, Mr. J. R. Guard, Mr. J. P. Levine, Mr. A. L. Mayer, Mr. D. A. Nelson, Mr. Guillermo Owen, Mr. W. H. Richter, Mr. P. A. Schweitzer, Mr. L. A. Shepp, Mr. R. E. Stearns, Mr. M. W. Syverson. Purdue University: Mr. Howard Banilower, Mr. G. W. Day, Mr. D. J. Eustice, Mr. A. T. Lauria, Mr. I. L. Lynn, Mr. E. C. Weinberg, Mr. F. M. Yaqub, Mr. W. J. Zimmer, Mr. P. J. Zwier.

Rice Institute: Mr, C. M. Pearcy, Jr., Mr. J. O. Koehl, Mr. T. J. Reed.

Tulane University: Mr. M. N. Bleicher, Mr. J. S. Givens, Jr., Miss Anne Lester.

Vanderbilt University: Mr. E. L. Wilson.

University of Virginia: Mr. Edwin Duda, Mr. J. A. Haley, Mr. C. W. Lemmon.

Wayne University: Mr. Stanley Fasbinder, Mr. Howard Garland, Mr. C. A. Schulz, Mr. A. J. Schwartz.

Yale University: Mr. M. L. Bender, Mr. Yuji Ito, Miss Elaine H. Koppelman, Mr. R. P. Langlands.

The Secretary announced that the following had been admitted to the Society in accordance with reciprocity agreements with various mathematical organizations: London Mathematical Society: Mr. W. A. Coppel, Mr. M. F. Newman, Mr. D. A. R. Wallace, Professor A. C. Woods; Société Mathématique de France: Dr. J. L. Lions, Mr. Yitzhak Katznelson; Wiskundig Genootschap te Amsterdam: Professor Gerrit Bol.

The following appointments by the President were reported: as a Committee to Confer with the Mathematical Association on Matters of Common Interest: C. B. Allendoerfer, E. G. Begle, H. F. Bohnenblust, Saunders MacLane, A. E. Meder, Chairman; as a Committee to Consider a New Type of Summer Seminar: L. S. Cohen, Chairman, J. L. Kelley, L. H. Loomis, R. L. Wilder; as a Committee to Consider Publishing Collected Works of Mathematicians: Garrett Birkhoff, Chair- 
man, J. H. Curtiss, G. A. Hedlund, Deane Montgomery, G. Szego; as a Committee to Award the Cole Prize in Algebra in 1959: Reinhold Baer, Chairman, Harish-Chandra, J. T. Tate; as a Committee to Nominate Officers and Members of the Council for 1960: Richard Courant, R. P. Dilworth, J. L. Doob, A. M. Gleason, G. T. Whyburn, Chairman; as an Arrangements Committee for the Summer Meeting in Salt Lake City in August, 1959: J. H. Barrett, L. K. Barrett, F. C. Biesele, W. J. Coles, Chairman, J. H. Curtiss, H. M. Gehman, I. O. Horsfall, N. C. Hunsaker, E. E. Kohlbecker, R. S. Pierce, D. W. Robinson, C. R. Wylie; as members of Committees to Select Hour Speakers: Summer and Annual Meetings: Hans Rademacher; at Eastern Meetings: Nathan Jacobson; at Western Meetings: Irving Kaplansky; at Far Western Meetings: Alfred Tarski; at Southeastern Meetings: J. J. Gergen; to the Applied Mathematics Committee: P. R. Garabedian, David Young; to the Joint Committee on Places of Meetings of the Association and Society: R. H. Bruck; to the Committee on Visiting Lectureships: M. H. Stone; to the Supervisory Committee for the Employment Register: R. M. Thrall; as Tellers for the 1958 election of officers and members of the Council: L. J. Paige, J. D. Swift; as Representatives on the Advisory Committee for the Fourth Berkeley Symposium on Mathematical Statistics and Probability to be held in 1960: J. H. Curtiss, J. L. Doob, W. Feller.

The following appointments to represent the Society were reported: at the inauguration of Gordon Richard Bennett as President of McMurray College: M. E. Mullings; at the inauguration of David Marion Delo as President of the University of Tampa: Carol S. Scott; at the inauguration of $M$. Norvel Young as President of Pepperdine College: D. V. Steed; at the inauguration of Lloyd Hartman Elliott as President of the University of Maine: Wilfred J. Combellack; at the inauguration of Charles Edwin Odegaard as President of the University of Washington: R. E. Gaskell; at the Inauguration of Harold Walter Stoke as President of Queens College, Jewell H. Buskey; at the inaugration of R. F. Oxnam as President of the Pratt Institute: A. D. Fialkow.

The Annual Meeting in January, 1961 was set in Washington, D. C. with New York as an alternate in case arrangements cannot be made in Washington. The Annual Meeting in 1962 was set in Kansas City, Missouri.

The council approved a recommendation by the Editors of the Transactions that four volumes, instead of three, of the Transactions be published in 1959. The Council also accepted the resignation of Professor S. S. Chern as a member of the Editorial Committee of the 
Transactions and elected Professor I. M. Singer to fill out his unexpired term. On recommendations of the Committee on Printing and Publishing, the Council approved the principle that henceforth royalties at prevailing commercial rates be paid to authors of Colloquium volumes, Surveys, and Proceedings of Summer Seminars in Applied Mathematics.

As the result of many suggestions that the ten minute papers at Society meetings be scheduled at specific times at fifteen minute intervals, the Council directed that this be tried at some forthcoming sectional meeting.

Following the award of the Bôcher Prize, the Business Meeting of the Society was held, Professor Everett Pitcher presiding. The Secretary reported briefly on the affairs of the Society. A motion was made from the floor by Professor Allen Shield and seconded by Professor Melvin Henriksen, that an item be placed on the agenda of the Business Meeting at the 1959 Summer Meeting in Salt Lake City to the effect that the Society should send an official letter to the proper authorities urging the readmission of Paul Erdös into this country. The motion was carried.

JoHN W. GREEN, Secretary

Everett Pitcher, Associate Secretary 